\title{
FAKTOR-FAKTOR DETERMINAN PADA MOTIVASI KERJA GURU SEKOLAH DASAR
}

\author{
Laura F.N. Sudarnoto \\ Prodi BK, FPB, Unika Atma Jaya, \\ Jl. Jendral Sudriman 51, Jakarta 12930 \\ Email: laurhan57@yahoo.com.
}

\begin{abstract}
The aim of this study is to describe the motivation of 121 teachers' work at private Elementary School in Jakarta. The study of research objects as determinant factors include teachers' commitment to school, the perception of leadership behaviors, and workplace conditions. Those variables are measured with assessment and behavior scale which the reliability is more than 0,90 . Results of this study show that there is a positive and significant relationship of the three determinant factors toward the motivations of work, either individually or collectively. The effort that needs to be followed up is to maintain headmasters' role as a leader because leadership is meaningful as a determinant factor that is important to increasing teachers' motivation of work.
\end{abstract}

Keywords: teachers' motivation of work, determinant factor

\begin{abstract}
Abstrak: Penelitian ini bertujuan untuk mendeskripsikan motivasi kerja 121 guru SD sekolah swasta di Jakarta. Kajian objek penelitian sebagai faktor determinan meliputi komitmen terhadap sekolah, persepsi terhadap perilaku kepemimpinan, dan kondisi tempat kerja. Variabel-variabel tersebut diukur dengan skala penilaian dan skala sikap yang memiliki reliabilitas masing-masing di atas 0,90 . Hasil penelitian menunjukkan adanya hubungan yang positif dan signifikan dari ketiga faktor determinan terhadap motivasi kerja, baik secara sendiri-sendiri maupun bersamasama. Usaha yang perlu ditindaklanjuti adalah mempertahankan peran kepala sekolah yang baik sebagai pimpinan karena kepemimpinan sangat bermakna sebagai faktor determinan yang penting untuk meningkatkan motivasi kerja para guru.
\end{abstract}

Kata kunci: motivasi kerja guru, faktor determinan

Perilaku manusia ditentukan oleh motif yang mendorong individu untuk melakukan aktivitas tertentu. Pilihan individu terhadap suatu jabatan atau profesi tertentu didukung pula oleh motiftertentu, baik secara intrinsik maupun secara ekstrinsik. Pengembangan motif individu mencapai tujuan atau sasaran tertentu merupakan proses motivasi. Setiap tenaga kerja mempunyai motivasi kerja yang berbeda sekalipun dalam lingkungan kerja yang sama.

Robbins (1991) mengemukakan motivasi kerja merupakan salah satu karakteristik yang ada pada individu sebagai tenaga kerja ketika masuk sebagai calon karyawan. Selama bekerja motivasi tersebut dapat mengalami perubahan sebagai hasil interaksi antara individu dengan lingkungan kerjanya. Motivasi kerja sebagai salah satu faktor dalam memprediksi kinerja atau unjuk kerja karyawan dengan didukung kemampuan internal dan lingkungan kerja akan menjadi faktor pendukung agar hasil kerja karyawan meningkat. Kinerja/unjuk kerja adalah hasil dari interaksi antara motivasi kerja, kemampuan, dan peluang.

Motivasi dapat dikatakan sebagai keseluruhan daya penggerak di dalam diri yang menimbulkan, 
menjamin kelangsungan, dan memberikan arah kegiatan, sehingga diharapkan tujuan dapat tercapai. Motivasi kerja guru merupakan salah satu kondisi yang mendorong guru melakukan pekerjaannya, yaitu kegiatan belajar mengajar secara lebih bersemangat sehingga akan memperoleh hasil pembelajaran yang lebih baik. Penelitian ini menelusuri faktorfaktor pendukung yang berperan sebagai anteseden implementasi motivasi kerja guru.

Ada beberapa elemen yang saling berinteraksi dan tidak dapat terpisah dalam proses motivasi kerja, antara lain peran kepemimpinan, kondisi tempat kerja, dan komitmen individu terhadap organisasi. Peran kepemimpinan adalah karakteristik perilaku pemimpin, karakteristik pengikut, dan situasi terjadinya interaksi pemimpin dan bawahan. Untuk menganalisis dan memahami sepenuhnya proses motivasi kerja tenaga kerja, elemen kepemimpinan harus diperhatikan. Menurut Popper \& Zakai (1994) analisis kepemimpinan dalam organisasi harus dihubungkan dengan konteks psikologis dalam organisasi, seperti hirarki (jarak dari pimpinan), hubungan pemimpin dengan superior, hakikat dari tugas organisasi (rutin atau berubah), dan kondisi yang terjadi (stabil versus krisis).

Kondisi lingkungan kerja, baik lingkungan fisik maupun lingkungan sosial, berperan dalam menciptakan kenyamanan dalam bekerja. Situasi lingkungan sekolah yang tidak kondusif diduga akan menurunkan motivasi kerja guru untuk mencapai kinerja yang maksimal. Demikian pula, sistem organisasi sekolah yang memberikan kenyamanan bekerja bagi guru diduga akan menimbulkan komitmen guru terhadap sekolah tersebut.

Berawal dari kondisi ini peneliti tertarik untuk menelusuri lebih lanjut mengenai motivasi kerja guru, khususnya di Sekolah Dasar dengan meninjau dari kepemimpinan kepala sekolah, komitmen organisasi, dan kondisi tempat kerja. Berdasarkan latar belakang masalah ditelusuri faktor-faktor yang mendukung motivasi kerja guru dari perspektif kompetensi manajerial sekolah, komitmen guru terhadap sekolah dan persepsi terhadap kondisi tempat kerja. Permasalahan yang akan ditelusuri terfokus pada pertanyaan penelitian sebagai berikut: (1) bagaimana persepsi guru terhadap mengenai manajemen sekolah?; (2) bagaimana komitmen guru terhadap organisasi sekolah?; (3) bagaimana persepsi para guru terhadap kondisi kerja yang dialami dalam lingkungan sekolah?; dan (4) sejauh mana kontribusi peran kondisi kerja, komitmen guru terhadap organisasi sekolah, persepsi terhadap manajerial sekolah dalam mendukung motivasi kerja guru?

Motif diartikan sebagai faktor yang mendorong individu untuk bertindak dengan cara tertentu. Motivasi merupakan proses psikologis yang mencerminkan interaksi antara sikap, kebutuhan, persepsi, dan keputusan yang terjadi pada diri individu. Motivasi individu untuk bekerja dapat dikembangkan oleh pimpinan karena pimpinan memberikan inspirasi, semangat, dan dorongan kepada bawahannya. Motivasi kerja sebagai keseluruhan daya penggerak di dalam diri karyawan dapat menimbulkan, menjamin kelangsungan, dan memberikan arah kegiatan kerja pada pencapaian tujuan.

Menurut Munandar (2001) usaha untuk meningkatkan motivasi individu dalam bekerja didukung oleh tiga peran, yaitu peran pemimpin, peran diri sendiri, dan peran organisasi. Ada dua cara pimpinan untuk meningkatkan motivasi kerja, yaitu bersikap keras dan memberi tujuan yang bermakna. Ancaman atau paksaan yang diberikan pimpinan kepada bawahan merupakan stimulasi agar bawahan bekerja keras, maka apabila bawahan tidak dapat menghindarkan diri dari situasi yang mengancam tersebut, akan bekerja keras. Sebaliknya, apabila bawahan menghargai nilai ketaatan kepada atasan, maka bawahan akan melakukan pekerjaan sebagai kewajiban dan tidak karena paksaan, dan hasil kerja akan bagus. Apabila bawahan memberi harkat yang tinggi pada nilai kemandirian dan merasa telah memiliki kemampuan untuk melakukan pekerjaan tanpa diperintah, maka bawahan akan merasakan pekerjaan sebagai suatu paksaan. Cara kedua adalah pimpinan memberikan tujuan yang bermakna yaitu pimpinan bersama-sama dengan bawahan menemukan kesepakatan tujuan-tujuan yang bermakna, sesuai dengan kemampuan yang dapat dicapai melalui prestasi kerjanya yang tinggi. Pada umumnya, sasaran tenaga kerja yang ingin dicapai dengan bekerja pada suatu organisasi kerja lebih dari satu sasaran. Pimpinan perlu mengenali sasaran-sasaran yang bernilai tinggi dari bawahannya agar dapat membantu bawahan untuk mencapainya dan dengan demikian pimpinan memotivasi bawahannya.

Karyawan juga dapat memotivasi diri melalui peran diri sendiri. Setiap individu mempunyai 
karakteristik, sistem nilai pribadi, dan tipe yang berbeda-beda dalam menghayati pekerjaannya. Ada tipe individu yang memiliki motivasi kerja reaktif yaitu dapat bekerja baik bila ada orang lain yang mendorong atau memacu individu untuk bekerja. Sebaliknya, individu yang memiliki motivasi kerja yang proaktif memandang kerja sebagai suatu kegiatan yang harus dilakukan dengan baik untuk tujuan-tujuan tertentu.

Adapun beberapa hasil penelitian yang mengatakan bahwa, motivasi kerja dipengaruhi oleh berbagai faktor. Beberapa faktor tersebut meliputi ketrampilan kepemimpinan kepala sekolah, kemampuan manajerial kepala sekolah, iklim kerja, dan sertifikasi profesi guru menjadi faktor meningkatnya motivasi kerja guru, karena berpengaruh secara positif dan signifikan (Karweti, 2010; Sukendar 2013; Darmana, dkk, 2013; Murwanti 2013)

Organisasi kerja dapat berperan meningkatkan motivasi kerja melalui penciptaan lingkungan kerja yang kondusif. Tempat kerja yang nyaman merupakan lingkungan tempat kerja yang dapat membuat karyawan merasa dihargai, dengan demikian mereka merasa bangga bekerja di lingkungan organisasi tersebut. Kondisi kerja adalah serangkaian kondisi atau keadaan lingkungan kerja yang dialami oleh setiap individu yang bekerja di dalam lingkungan tersebut. Persepsi terhadap kondisi kerja merupakan penghayatan situasi dalam lingkungan kerja atau kondisi eksternal dalam lingkungan tempat kerja yang berperan dalam pengalaman kerja karyawan. Kondisi kerja adalah serangkaian kondisi atau keadaan lingkungan kerja yang dialami oleh setiap individu yang bekerja di dalam lingkungan tersebut. Persepsi terhadap kondisi kerja merupakan penghayatan situasi dalam lingkungan kerja atau kondisi eksternal dalam lingkungan tempat kerja yang berperan dalam pengalaman kerja karyawan (Sudarnoto, 2015). Oleh sebab itu, kondisi kerja yang terdiri dari faktor-faktor seperti kondisi fisik, kondisi psikologis, dan kondisi sementara dari lingkungan kerja, harus diperhatikan agar para pekerja dapat merasa nyaman dalam bekerja sehingga dapat meningkatkan motivasi dan produktivitas kerja.

Selain penciptaan kondisi kerja, berbagai kebijakan dan peraturan dalam organisasi kerja dapat menarik atau mendorong motivasi kerja para karyawannya. Salah satu contoh kebijakan yang dilakukan oleh organisasi adalah kegiatan Gugus Kendali Mutu (GKM = Quality Circles) yang merupakan satu kebijakan yang dituangkan ke dalam berbagai peraturan yang mendasari kegiatan dan yang mengatur pertemuan pemecahan masalah dalam kelompok kecil. Kebijakan lain yang berkaitan dengan motivasi kerja ialah kebijakan di bidang imbalan keuangan. Selain gaji pokok, juga diberikan insentif atau bonus pekerjaan tambahan atau prestasi kerja yang sangat luar biasa telah dilakukan oleh tenaga kerja. Hal ini tentu akan semakin meningkatkan motivasi kerja individu yang telah bekerja dengan maksimal.

Komitmen seseorang terhadap organisasi atau perusahaan seringkalimenjadiisuyang sangatpenting. Oleh karena pentingnya hal tersebut, maka beberapa organisasi menentukan unsur komitmen sebagai salah satu syarat untuk memegang suatu jabatan atau posisi yang ditawarkan dalam iklan-iklan lowongan pekerjaan. Menurut Steers (dalam Siegel \& Lane, 1987), komitmen organisasi didefinisikan sebagai rasa identifikasi (kepercayaan terhadap nilai-nilai organisasi), keterlibatan (kesediaan untuk berusaha sebaik mungkin demi kepentingan organisasi) dan loyalitas (keinginan untuk tetap menjadi anggota organisasi yang bersangkutan) yang dinyatakan oleh seorang pegawai terhadap organisasinya. Komitmen terhadap organisasi merupakan kelekatan individu lebih dari sekedar keanggotaan formal, karena meliputi sikap menyukai organisasi dan kesediaan untuk mengusahakan tingkat upaya yang tinggi bagi kepentingan organisasi demi pencapaian tujuan. Berdasarkan definisi ini bahwa dalam komitmen organisasi tercakup unsur loyalitas terhadap organisasi, keterlibatan dalam pekerjaan, dan identifikasi terhadap nilai-nilai dan tujuan organisasi.

Menurut Mowday, et al. (dalam Allen \& Meyer, 1990), definisi komitmen lainnya adalah kekuatan yang bersifat relatif dari individu dalam mengidentifikasikan keterlibatan dirinya ke dalam bagian organisasi. Komitmen ini dapat ditandai dengan tiga hal yaitu penerimaan terhadap nilainilai dan tujuan organisasi, kesiapan, dan kesediaan untuk berusaha dengan sungguh-sungguh atas nama organisasi dan keinginan untuk mempertahankan keanggotaan di dalam organisasi (menjadi bagian dari organisasi). Secara singkat, pada intinya beberapa definisi komitmen organisasi dari beberapa ahli mempunyai penekanan yang hampir 
sama yaitu proses pada individu (karyawan) dalam mengidentifikasikan dirinya dengan nilai-nilai, aturan-aturan, dan tujuan organisasi.

Menurut Allen \& Meyer (1990) komitmen organisasi terdiri atas tiga komponen, yaitu (1) komponen afektif yang didefinisikan sebagai taraf keterikatan seseorang secara psikologis terhadap organisasi kerjanya melalui perasaan seperti kesetiaan, afeksi, dan rasa memiliki. Dengan kata lain, komponen ini menunjuk pada keterikatan pada emosional atau kelekatan karyawan pada organisasi kerjanya; (2) komponen kontinuitas berarti komponen berdasarkan persepsi pegawai tentang kerugian yang akan dihadapinya jika ia meninggalkan organisasi. Komponen ini menunjuk pada komitmen yang berdasarkan pada pertimbangan keuntungan dan kerugian atau pengaruh negatif yang ditimbulkan bila karyawan meningglakan organisasi tersebut; dan (3) komponen normatif merupakan perasaan-perasaan pegawai tentang kewajiban yang harus diberikan kepada organisasi. Komponen ini meliputi komponen moral karena menunjuk pada perasaan karyawan tentang kewajiban atau tanggung jawab untuk tetap bertahan dalam organisasi tersebut.

Menurut Mowday, et al. (dalam Allen \& Meyer, 1990), komitmen organisasi memiliki dua komponen, yaitu sikap dan kehendak untuk bertingkah laku. Sikap mencakup (1) identifikasi dengan organisasi yaitu penerimaan tujuan organisasi, dimana penerimaan ini merupakan dasar komitmen organisasi. Identifikasi pegawai tampak melalui sikap menyetujui kebijaksanaan organisasi, kesamaan nilai pribadi dan nilai-nilai organisasi, rasa kebanggaan menjadi bagian dari organisasi; (2) keterlibatan sesuai peran dan tanggungjawab pekerjaan di organisasi tersebut. Karyawan yang memiliki komitmen tinggi akan menerima hampir semua tugas dan tanggung jawab pekerjaan yang diberikan padanya; dan (3) kehangatan, afeksi dan loyalitas terhadap organisasi merupakan evaluasi terhadap komitmen, serta adanya ikatan emosional dan keterikatan antara organisasi dengan pegawai. Karyawan dengan komitmen tinggi merasakan adanya loyalitas dan rasa memiliki terhadap organisasi. Kehendak untuk bertingkah laku mencakup dua hal, yaitu (1) kesediaan untuk menampilkan usaha. Hal ini tampak melalui kesediaan bekerja melebihi apa yang diharapkan agar organisasi dapat maju. Karyawan dengan komitmen tinggi, ikut memperhatikan nasib organisasi dan (2) keinginan tetap berada dalam organisasi. Pada karyawan yang memiliki komitmen tinggi, hanya sedikit alasan untuk keluar dari organisasi dan berkeinginan untuk bergabung dengan organisasi yang telah dipilihnya dalam waktu lama. Menurut Mowday, et.al. (dalam Allen \& Meyer, 1990), pengalaman kerja karyawan sangat berpengaruh pada tingkat komitmen karyawan pada organisasi kerja. Faktor-faktor yang mempengaruhi kelekatan individu terhadap perusahaan adalah (1) keterandalan organisasi, (2) perasaan dihargai, dan (3) tingkat keterlibatan sosial.

Louis (dalam Ahmad \& Razak, 2007) menjelaskan empat jenis komitmen guru. Keempat hal tersebut meliputi komitmen terhadap sekolah sebagai satu unit sosial, komitmen terhadap kegiatan akademik sekolah, komitmen terhadap peserta didik sebagai individu yang unik, dan komitmen untuk menciptakan pengajaran bermutu. Komitmen guru terhadap kegiatan akademik sekolah dijabarkan dari peran guru, yaitu guru sebagai perancang pembelajaran, guru sebagai pengelola pembelajaran, guru sebagai pengarah pembelajaran, guru sebagai pelaksana kurikulum, dan guru sebagai evaluator.

Kepemimpinan merupakan aktivitas yang bersifat dinamis. Pemimpin adalah individu yang mengetahui apa yang harus dikerjakan pada saat tertentu, yang memiliki kecakapan dan kemampuan untuk mempengaruhi dan mengajak, mengumpulkan dan menggerakkan orang-orang lain untuk mencapai tujuan bersama atau menangani masalah yang ada. Selain itu, pemimpin adalah orang-orang yang mampu membina orang-orang lain membentuk suatu kesatuan kerja dan bersama-sama mereka rela bekerja, bahkan terkadang berkorban demi terselesaikannya tugas atau pekerjaan tertentu untuk kepentingan bersama. Setiap pemimpin mempunyai sifat, kebiasaan, temperamen, dan kepribadian sendiri yang khas sehingga tingkah laku dan gaya pemimpin berbeda satu sama lain. Gaya atau style hidup seorang pemimpin ini pasti akan mewarnai perilaku dan tipe kepemimpinannya, sehingga muncullah beberapa gaya kepemimpinan. Salah satu teori yang berkembang akhir-akhir ini adalah perilaku kepemimpinan transaksional dan transformasional.

Perkembangan terbaru dari teori kepemimpinan adalah konsep otoritas karismatik dari Weber, yang dilanjutkan oleh House. Perluasan proposisi House 
dilakukan oleh Bass (1985). Bassmengemukakantipe kepemimpinan transaksional dan transformasional, dan kepemimpinan karismatik merupakan salah satu komponen dari tipe transformasional. Menurut Umstod (1988), pemimpin karismatik berperilaku dalam cara: (1) role modeling, sebagai model yang kompeten, atraktif, dan sukses; (2) image building, membangun citra yang dipandang menyenangkan oleh orang lain; (3) transcendent goals, ada visi di masa depan dengan tujuan ideologis berdasarkan moral; (4) high expectational, mempertinggi harga diri para pengikut; dan (5) motivation, mampu membangkitkan motivasi pengikut terhadap penyelesaian misi organisasi. Hasil penelitian Kudisch (1995) menggambarkan bahwa karisma adalah konsepsi yang secara empiris berbeda dari kekuasaan referensi (referent power) dan kekuasaan ahli (expert power).

Pada dasarnya kepemimpinan adalah suatu proses sosial yang meliputi persepsi dan interaksi antara pemimpin dan pengikut. Ada suatu pertukaran antara pemimpin dan pengikut yang disebut proses pertukaran sosial atau kepemimpinan transaksional. Pemimpin dan bawahan mengatur suatu proses pertukaran (transaksi). Menurut Bass (1985), ada dua komponen yang merupakan kepemimpinan transaksional. Pertama, pemberian imbalan tergantung (reward contingent). Kedua, manajemen dengan kekecualian (managementby-exception). Pada perkembangan selanjutnya komponen kepemimpinan transaksional dibedakan menjadi manajemen pengecualian aktif dan manajemen pengecualian pasif. Berdasarkan dua komponen tersebut terjadi empat macam transaksi, yaitu: (1) transaksi imbalan adalah apabila bawahan melakukan tugas atau pekerjaan yang menguntungkan organisasi maka diberi imbalan yang setimpal; (2) transaksi manajemen pengecualian aktif adalah atasan mengawasi bawahan dengan ketat, jika akan timbul kesalahan maka akan dibantu; (3) transaksi manajemen pengecualian pasif adalah atasan baru bertindak setelah terjadi kegagalan atau jika bawahan bertindak salah, (4) transaksi laissez-faire adalah atasan memberikan bawahannya melakukan tugas tanpa ada pengawasan dari atasan, kualitas kerja seluruhnya adalah tanggungjawab bawahan. Keempat komponen ini menunjukkan adanya derajat kepercayaan dari atasan terhadap bawahan yang berbeda-beda. Untuk mengetahui perilaku yang profesionalisme diperlukan pembinaan secara bertahap (Herianto, 2012). Peran atasan dalam kepemimpinan transaksional adalah mempengaruhi bawahan dengan membangkitkan atau mendorong hasrat kerja bawahan berdasarkan pemberian faktor eksternal yang menguntungkan atau berdampak positif bagi bawahan.

Menurut Bass (1985), kepemimpinan transformasional telah menjadi suatu kebutuhan dalam dunia kerja pada pasca-industri. Aspek positif kepemimpinan transformasional didukung oleh pandangan Yukl (1989) bahwa kepemimpinan transformasional dipandang terutama dari segi pengaruh pimpinan terhadap para pengikut dan perilaku yang dilakukan untuk mencapai pengaruh tersebut. Para pengikut merasa yakin, kagum, setia, dan hormat terhadap pemimpinnya. Mereka termotivasi untuk bekerja lebih giat dari apa yang sebenarnya diharapkan sebelumnya.

Pemimpin transformasional dapat menggerakkan pengaruhnya demi kepentingan kelompok, organisasi, atau negara daripada kepentingan selfinterest mereka sendiri. Pemimpin transformasional berusaha agar mereka dapat mengubah konsep diri bawahan dan meningkatkan bawahan mereka menjadi orang-orang yang dapat mencapai aktualisasi diri, regulasi diri, dan kontrol diri. Teori kepemimpinan transformasional pada haki-katnya menjelaskan proses hubungan antara atasan dan bawahan yang didasari oleh nilai-nilai, keyakinan, dan asumsi mengenai visi dan misi organisasi. Kepemimpinan transformasional dapat dicapai dalam salah satu dari tiga cara yang saling berhubungan, yaitu (1) menimbulkan taraf kesadaran bawahan mengenai kepentingan dan nilai-nilai dari hasil yang ditunjuk dan cara-cara untuk mencapainya; (2) mengajak bawahan untuk melampaui self-interest sendiri demi untuk kepentingan tim, organisasi, atau politis yang lebih luas; dan (3) mengubah taraf kebutuhan bawahan pada hirarkhi kebutuhan (menurut Maslow) atau memperluas lingkup kebutuhan dan keinginan bawahan.

Bass (1985) mengemukakan tiga komponen dalam kepemimpinan transformasional. Pertama, karisma adalah kualitas mistik dan daya tarik kepribadian pemimpin yang membangkitkan pengaruh dan power referensi yang besar. Kedua, stimulasi intelektual adalah bagaimana bawahan didorong untuk berpikir mengenai problemperoblem lama dalam cara yang baru, dengan 
demikian dicetuskan kesadaran yang lebih luas dan dihasilkan solusi yang kreatif. Ketiga, pertimbangan individual adalah bagaimana pemimpin memperoleh pengakuan kekuasaan melalui bantuannya sebagai seorang mentor dan menggunakan orientasi perkembangan dengan bawahan. Perkembangan selanjutnya, Bass menjabarkan menjadi lima aspek atau komponen kepemimpinan transformasional (Munandar, 2001).

Attributed charisma (karisma sebagai sifat yang berhubungan). Pemimpin menimbulkan kesan pada bawahan bahwa ia memiliki keahlian untuk melakukan pekerjaannya sehingga patut dihargai. Karisma merupakan label yang dibuat oleh bawahan dan atasan sendiri tidak menyadari akan karismanya.

Intellectual stimulation (stimulasi intelektual). Bawahan merasa bahwa pimpinan mendorong mereka untuk memikirkan kembali cara kerja mereka, mencari cara baru dalam melaksanakan tugas, dan merasa mendapatkan cara baru dalam mempersepsi tugas mereka.

Individualized consideration (pertimbangan individual). Pemimpin memperlakukan setiap bawahannya sebagai seorang pribadi dengan kecakapan, kebutuhan, dan keinginannya masingmasing. Pemimpin menimbulkan rasa mampu pada bawahannya.

Inspirational motivation (motivasi yang menimbulkan inspirasi). Pemimpin mampu menimbulkan inspirasi pada bawahannya dengan mengubah konsep diri bawahan sehingga bawahan mau melakukan tugasnya atas dorongan atau kerelaan dari dalam dirinya sendiri.

Idealized influence (pengaruh mencapai nilai idealisme). Pemimpin berusaha, melalui pembicaraan, mempengaruhi bawahan dengan menekankan pentingnya nilai-nilai dan keyakinan, perlu dimiliki tekad mencapai tujuan, perlu diperhatikan akibat moral dan etik dari keputusan yang diambil.

Teori Bass mengenai konseptualisasi kepemimpinan transaksional dan kepemimpinan transformasional telah dikaji ulang dan dinilai lebih lanjut oleh Bycio, et.al. (1995). Hasil penelitian mereka dengan analisis faktor konfirmatori menunjukkan dukungan terhadap ketiga komponen kepemimpinan transformasional dan kedua komponen kepemimpinan transaksional.

Pemimpin transformasional dinilai lebih efektif daripada pemimpin transaksional. Kepemimpinan transformasional memperendah tingkat berhenti atau keluarnya karyawan, meningkatkan produktivitas, dan kepuasan karyawan (Robbins, 1991). Kelebihan teori kepemimpinan transformasional adalah memberikan sumbangan dalam memahami proses kepemimpinan, yaitu bagaimana seorang pemimpin mempengaruhi para pengikutnya untuk berkorban, kesediaan terhadap pencapaian tujuan, dan melakukan lebih banyak dari apa yang diharapkan. Selain aspek positif, ada pula kelemahan teori transformasional.

Menurut Popper \& Zakai (1994), ada perbedaan kondisi yang mengakibatkan keunggulan dari tiap pola kepemimpinan. Kondisi yang tepat bagi kepemimpinan transaksional adalah situasi yang rutin, yaitu taraf kecemasan tidak tinggi, tidak ada ancaman krisis di masa mendatang atau perubahan besar. Kondisi yang tepat bagi kepemimpinan transformasional adalah taraf kecemasan yang tidak tinggi dan atensi diberikan bagi kebutuhan perkembangan, pola ini lebih tergantung pada pandangan pimpinan sebagai transformasional dan kurang tergantung pada konteks organisasi. Sekalipun kedua tipe kepemimpinan ini berbeda, tetapi hasil penelitian yang dilakukan oleh Pillai, et al. (1999) menunjukkan ada hubungan yang bermakna antara kepemimpinan transaksional dan kepemimpinan transformasional.

\section{METODE}

Subjek penelitian adalah guru-guru dari 15 SD swasta Katolik di wilayah DKI. Instrumen penelitian diujicobakan pada 56 guru dari 4 SD. Subjek penelitian sebanyak 121 guru dari 11 SD. Variabel penelitian meliputi variabel motivasi kerja, komitmen organisasi, kondisi tempat kerja, dan persepsi terhadap perilaku kepemimpinan. Untuk mengukur variabel penelitian digunakan instrumen skala penilaian dan skala sikap. Berdasarkan hasil uji coba instrumen diperoleh pernyataan-pernyataan yang valid dan koefisien reliabilitas dari keempat instrumen penelitian di atas 0,90 . Penelitian ini merupakan survey dengan rancangan korelatif. Data dianalis dengan teknik analisis deskriptif dan analisis regresi ganda.

\section{HASIL DAN PEMBAHASAN}

Untuk mendapatkan deskripsi tentang tingkatan motivasi kerja guru, dibuat klasifikasi dengan lima 
kategori. Data pada tabel 1 menunjukkan hampir separuh $(49 \%)$ dari subjek penelitian berada pada motivasi kerja yang sangat tinggi, demikian pula pada kategori tinggi sebanyak $48 \%$ dan hanya 3\% guru yang berada pada motivasi kerja kategori cukup. Deskripsi data ini memberikan gambaran bahwa sebagian besar guru-guru SD di 11 sekolah, sebagai unit analisis penelitian ini, memiliki motivasi kerja yang tinggi dan sangat tinggi. Motivasi kerja merupakan penggerak yang positif bagi guru sehingga mereka dapat berkarya dan memberikan layanan yang optimal bagi peserta didik.

Tabel 1. Klasifikasi Motivasi Kerja Guru

\begin{tabular}{|c|c|c|c|}
\hline Rentang Skor & Kategori & Frekuensi & Persentase \\
\hline $147-175$ & $\begin{array}{l}\text { Sangat } \\
\text { tinggi }\end{array}$ & 60 & 49 \\
\hline $119-146$ & Tinggi & 58 & 48 \\
\hline $91-118$ & Cukup & 3 & 3 \\
\hline $63-90$ & Rendah & 0 & 0 \\
\hline $35-62$ & $\begin{array}{l}\text { Sangat } \\
\text { rendah }\end{array}$ & 0 & 0 \\
\hline TOTAL & & 121 & 100 \\
\hline
\end{tabular}

Berdasarkan hasil analisis korelatif pada tabel 1, baik secara berpasangan maupun bersamasama, menunjukkan korelasi yang positif dan signifikan pada taraf signifikansi 5\%. Hasil korelasi berpasangan yang terbesar pada hubungan antara persepsi terhadap perilaku kepemimpinan dengan motivasi kerja guru yaitu sebesar 0,341. Hal ini mengindikasikan persepsi guru yang positif terhadap perilaku atau peranan kepala sekolah sangat berarti untuk meningkatkan motivasi kerja guru. Hasil penelitian ini mendukung kajian yang telah dilakukan oleh Munandar (2001) bahwa usaha untuk meningkatkan motivasi individu dalam bekerja didukung oleh tiga peran, yaitu peran pemimpin, peran diri sendiri, dan peran organisasi. Salah satu peran yang dapat meningkatkan motivasi kerja guru adalah Kepala Sekolah yang mampu menjalankan kepemimpinan sekolah, khususnya dengan kepemimpinan transformasional.

Hasil korelasi antara komitmen terhadap sekolah dengan motivasi kerja guru sebesar 0,293, hal ini menunjukkan hubungan yang positif dan signifikan. Guru yang loyal dan merasa terlibat sebagai bagian dari sekolah dapat meningkatkan semangat dan dorongannya untuk bekerja lebih baik lagi. Hasil penelitian ini sejalan dengan pendapat yang telah dikemukakan oleh Steers (dalam Siegel \& Lane, 1987) yaitu komitmen terhadap organisasi merupakan kelekatan individu lebih dari sekedar keanggotaan formal, karena meliputi sikap menyukai organisasi dan kesediaan untuk mengusahakan tingkat upaya yang tinggi bagi kepentingan organisasi demi pencapaian tujuan. Dengan kata lain, guru yang memiliki kelekatan dengan sekolah memiliki unsur loyalitas terhadap sekolah, keterlibatan dalam pekerjaan, dan identifikasi terhadap nilai-nilai dan tujuan sekolah. Untuk dapat meningkatkan kinerja guru demi tercapainya kriteria ketuntatasan minimal dapat dilaksanakan melalui workshop (Sudiati \& Tatik, 2015). Komitmen terhadap sekolah ini dapat meningkatkan dorongan guru untuk melakukan perannya sebaik mungkin sebagai pendidik di sekolah.

Hal lain, yang juga mendukung motivasi kerja guru adalah kondisi kerja atau lingkungan sekolah tempat guru bekerja. Hasil korelasi antara kondisi kerja dengan motivasi kerja guru sebesar 0,281 , hal ini menunjukkan adanya hubungan yang positif dan bermakna. Hal ini, secara otomatis sikap guru terhadap peserta didik ada fenomena positip (Yuzarion \& Kardo, 2015). Semakin positif persepsi guru terhadap lingkungan dan kondisi kerja di sekolah maka semakin tinggi dorongan dan semangat kerja guru untuk bekerja. Kondisi ini didukung oleh kajian yang telah dilakukan oleh Sudarnoto (2015) bahwa kondisi kerja adalah situasi dalam lingkungan kerja atau kondisi eksternal dalam lingkungan tempat kerja yang berperan dalam pengalaman kerja karyawan. Pengalaman dan persepsi yang positif terhadap kondisi kerja tentu akan berdampak dalam semangat kerja dan kinerja yang dilaksanakan.

\section{Tabel 2. Hasil Analisis Korelatif}

\begin{tabular}{lcc}
\hline \multicolumn{1}{c}{\begin{tabular}{c}
\multicolumn{1}{c}{ Variabel } \\
Independen
\end{tabular}} & $\begin{array}{c}\text { Motivasi } \\
\text { Kerja }\end{array}$ & Signifikansi \\
\hline $\begin{array}{l}\text { Komitmen organisasi } \\
(\mathrm{KO})\end{array}$ & 0,293 & 0,01 \\
$\begin{array}{l}\text { Persepsi terhadap } \\
\text { kepemimpinan (PK) }\end{array}$ & 0,341 & 0,00 \\
$\begin{array}{l}\text { Kondisi tempat kerja } \\
\text { (KTK) }\end{array}$ & 0,281 & 0,01 \\
KO, PK, \& KTK & 0,390 & 0,00 \\
\hline
\end{tabular}

Berdasarkan pada tabel 2 di atas, hasil korelasi secara bersama-sama dari variabel komitmen terhadap sekolah, persepsi terhadap perilaku 
kepemimpinan, dan kondisi tempat kerja dengan motivasi kerja guru menunjukkan koefisien korelasi sebesar 0,390, hasil tersebut signifikan pada taraf signifikansi $1 \%$. Koefisien determinasi dari ketiga variabel independen tersebut dengan motivasi kerja sebesar $15 \%$. Hal ini berarti sumbangan ketiga variabel tersebut terhadap motivasi kerja sebanyak $15 \%$ dan sisanya $(85 \%)$ dijelaskan oleh variabel lainnya yang tidak dianalisis dalam penelitian ini.

\section{SIMPULAN DAN SARAN}

\section{Simpulan}

Pertama, sebagian besar subjek penelitian (guru SD dari 11 sekolah swasta di DKI Jakarta) memiliki motivasi kerja yang sangat tinggi dan tinggi.

Kedua, hasil analisis korelatif antara komitmen organisasi, persepsi terhadap perilaku kepala sekolah, dan kondisi tempat kerja terhadap motivasi kerja guru menunjukkan korelasi yang positif dan signifikan. Ketiga variabel tersebut sebagai faktor-faktor determinan yang dapat meningkatkan motivasi kerja guru. Determinan yang paling berperan adalah persepsi guru terhadap kepemimpinan kepala sekolah.

Ketiga, hasil korelasi secara bersama-sama dari komitmen organisasi, persepsi terhadap perilaku kepala sekolah, dan kondisi tempat kerja terhadap motivasi kerja guru menunjukkan korelasi yang signifikan dengan koefisien determinasi sebesar $15 \%$.

\section{Saran}

Pertama, peran kepala sekolah sangat penting dalam membina suasana akademik dan relasi yang harmonis dengan warga sekolah, khususnya dengan staf guru dan Komite Sekolah. Persepsi yang positif terhadap perilaku dan peran kepala sekolah dapat menciptakan semangat kerja para guru untuk berkarya lebih optimal. Kepala Sekolah perlu memberikan kesempatan untuk berdialog dengan staf guru, selain pada forum formal dalam rapat.

Kedua, kondisi tempat kerja perlu diperhatikan dalam lingkungan sekolah karena kondisi kerja yang kondusif dapat menambah semangat kerja guru sehingga dapat pula meningkatkan motivasi guru untuk bekerja lebih maksimal. Penyediaan lingkungan fisik yang memadai perlu diusahakan oleh pihak sekolah, baik untuk sarana kerja guru maupun untuk proses pembelajaran di sekolah.
Kepala Sekolah bersama guru dapat menciptakan lingkungan sosial yang kompak dengan alur komunikasi yang terbuka dan transparan.

Ketiga, kelekatan dan kesetiaan guru terhadap organisasi sekolah dan merasa sebagai bagian dalam sekolah perlu ditingkatkan. Bila guru merasakan bahwa kepentingan sekolah juga merupakan kepentingan dirinya tentu peningkatan mutu dapat dilakukan secara sinergis dan koordinatif.

\section{DAFTAR RUJUKAN}

Ahmad \& Razak. 2007. Komitmen Guru. Yogyakarta: Erlangga

Allen, N.J. \& Meyer, J.P. 1990. The Measurement and Antecedents of Affective, Continuance, and Normative Commitment to the Organization. Journal of Occupational Psychology, 63:1- 18.

Bass, B.M. 1985. Leadership and Performance Beyond Expectations. London: The Free Press.

Bycio, P., Hackett, R.D. \& Allen, J.S. 1995. Futher Assessments of Bass's (1985) Conceptualization of Transactional and Transformational Leadership. Journal of Applied Psychology, 80:460-478.

Damana, I.K., Dantes, N., \& Natajaya, N. 2013. Kontribusi Kompetensi Manajerial Kepala Sekolah, Iklim Kerja, dan Motivasi Kerja terhadap Kinerja Guru SMP Se Kecamatan Mendoyo Kabupaten Jembrana. Jurnal Pendidikan Dasar. 3:1-12.

Herianto, E. 2012. Pembinaan Pascapelatihan dalam Membentuk Perilaku Profesional. Jurnal Sekolah Dasar. 21(2):32-43

Karweti, E. 2010. Pengaruh Kemampuan Manajerial Kepala Sekolah dan Faktor yang Mempengaruhi Motivasi Kerja terhadap Kinerja Guru SLB di Kabupaten Subang. Jurnal Penelitian Pendidikan. 11(2):77-89.

Kudisch, J.D. 1995. Expert Power, Referent Power, and Charisma : Toward the Resolution of Theorethical Debate. Journal of Business and Psychology, 10(1):177-194.

Munandar, A.S. 2001. Psikologi industri dan organisasi. Jakarta: UI Press.

Murwanti, H. 2013. Pengaruh Sertifikasi Profesi Guru terhadap Motivasi Kerja dan Kinerja Guru di SMK Negeri Se-Surakarta. Jurnal Pendidikan Bisnis dan Ekonomi (BISE). 1(1):12-21 
Pillai, R., Schriesheim, C.A., and Williams, E.S. 1999. Fairness peceptions and trust as mediators for transformational and transactional leadership. Journal of Management, 25(2):897-933.

Popper, M., \& Zakkai, E. 1994. Transactional, Charismatic, and Transformational Leadership. Leadership \& Organization Development Journal, 15(6):3-7.

Robbins, S. P. 1991. Organizational Behavior. Englewood Cliffs, NJ : Prentice Hall.

Siegel,L.\&Lane.I.M. 1987.PersonnelandOrganizational Psychology, (second edition). New York: Wiley

Sudarnoto, L.F.N. 2015. Psikologi organisasi, Kajian teoretis dan riset. Jakarta: Penerbit Universitas Katolik Indonesia Atma Jaya

Sudiati, Tatik. 2015. Peningkatan Kinerja Guru dalam Menetapkan Kriteria Ketuntasan Minimal Melalui Worskshop. Jurnal Ilmu Pendidikan. 42(2):33-45
Sukendar, N.C.E. 2013. Pengaruh Keterampilan Kepemimpinan Kepala Sekolah dan Motivasi Kerja Guru terhadap Kinerja Guru SMP Negeri di Sub Rayon 03 Kabupaten Jepara. JMP. 2(1):67-84.

Umstod, D. 1988. Understanding Organizational Behavior. St Paul : West Publishing Company.

Yukl, G. 1989. Leadership in Organization. Englewood Cliffs, New Jersey : Prentice-Hall, Inc.

Yuzarion \& Kardo, R. 2015. Sikap Guru Terhadap Peserta Didik dalam Belajar. Jurnal Ilmu Pendidikan. 42(2):44-56 